\title{
Sibul, kadakas ja küüslauk - toidutaimed ja regionaalne toidukultuur Eestis ${ }^{1}$
}

\author{
Raivo Kalle, Ester Bardone, Renata Sõukand
}

Teesid: Toidukultuuri seisukohalt on regioon ühtaegu ajalooline ja geograafiline, kultuuriline ja looduslik, materiaalne ja kujutluslik üksus. Kindla piirkonnaga seostamine kujundab toidust sümboolse identiteedimarkeri. Kolme regionaalse kulinaarse sümboli - Peipsi-äärne sibul, Saaremaa kadakas ja Jõgeva küüslaugufestivali keskmes olev küüslauk - najal analüüsime seda, kuidas saab üks piirkond määratleda end konkreetse taime abil nii kultuuriliselt kui ka majanduslikult, ning uurime, milline roll on toidutootjatel ja turismitööstusel Eesti piirkondlike toidutraditsioonide kujundamisel rahvusvaheliste arengute kontekstis. Sarnaselt Euroopaga kujundavad ka Eestis regionaalse toidukultuuri ametlikku kuvandit tippkokad ja/või toidutootjad. Väidame, et Peipsi-äärse sibula kasvatamist ja kasutamist soosivad nii ajaloolised traditsioonid kui ka keskkonnatingimused, kadaka tarvitamine Saaremaa toidukultuuris tuleneb selle looduslikust levikust, Jõgeva küüslaugufestival on aga näide kohaturunduse eesmärgil leiutatud traditsioonist.

Märksõnad: Jõgeva küüslaugufestival, küüslauk, Peipsi-äärne sibul, regionaalne toidukultuur, Saaremaa kadakas

Toiduks kasutatavate taimede valik on Eestis oluliselt mitmekesisem kui toiduks tarvitatavate loomade-lindude hulk. Eestlased on harjunud end määratlema loodusrahvana ning toidutaimed on hea näide looduse ja kultuuri lõimumisest - seda, mida inimesed on söönud, on oluliselt mõjutanud keskkond, see, mis antud piirkonnas kasvab ja mida on võimalik kasvatada. Jättes praegu kõrvale kasvutingimustest tuleneva üldise toidutaimede regionaalse variatiivsuse, mis on kahtlemata olemas isegi väikeses Eestis, keskendume kolmele toidutaimele. Viimastest on nii kujunenud kui ka kujundatud kolme piirkonna kulinaarsed sümbolid ja ühtaegu kaubamärgid. Vaatlusalusteks taimedeks on kaks kultuurtaime - harilik sibul (Peipsi-äärne piirkond) ja küüslauk (Jõgeva linn) - ning üks looduslik liik - harilik kadakas (Saaremaa). ${ }^{2}$ Need kolm näidet oleme valinud, soovides analüüsida regioonide kulinaarsete sümbolite seoseid 
piirkonna ajaloo ja traditsioonidega, tänapäeva regionaalseks sümboliks saamise teid ning erinevusi vastava taime kui piirkonna märgi propageerimisel. Näidete varal arutleme, kuidas saab üks piirkond end konkreetse taime kaudu määratleda, ning uurime, milline roll on toidutootjatel ja turismitööstusel Eesti regionaalsete toidutraditsioonide kujundamisel rahvusvaheliste arengute kontekstis.

\section{Toidukultuuri taasregionaliseerumisest Euroopas ja Eestis}

Regionaalsust võib toidukultuuri puhul mõista mitmeti. Regiooni mõiste on Euroopa toidukultuuri kontekstis jätkuvalt aktuaalne, ehkki uurijad on juhtinud tähelepanu regiooni ja regionaalsuse ambivalentsusele terminitena nende mõistete tähendus on sageli konteksti-spetsiifiline ja sõltub sellest, mida konkreetsed kasutajad (nt poliitikud või toidutootjad) silmas peavad (Kneafsey 2010). Vaatamata mõistelisele kimbatusele võib siiski väita, et toiduregioonidest rääkimine tõstatab olulisi küsimusi, nt: mille poolest eristub üks regioon teisest?; kuidas mõjutab geograafiline piirkond inimeste kulinaarset ja laiemalt kultuurilist identiteeti?; mil moel säilivad või leiavad uuesti kinnitamist regionaalsed eripärad üha globaliseeruvamas maailmas? (Bell \& Valentine 1997: 147).

Toidukultuuri seisukohalt on regioon korraga ajalooline ja geograafiline, kultuuriline ja looduslik, materiaalne ja kujutluslik. Piirkonna maitsebuketti ei kuulu ainult kultiveeritud, vaid ka looduses kasvav toit (vrd Trubek 2008). Erinevates diskursustes samastatakse nii Euroopas kui ka Eestis regiooni gastronoomiat mõnikord rahvusköögiga (nt Itaalia köök; Eesti köök) ja mõnikord kitsama kultuurilise piirkonna toiduga (nt Toskaana köök; seto köök). Regioon võib aga hõlmata ka rahvusriikidest laiemaid areaale, mille puhul räägitakse piirkonnale omasest dieedist (nt Vahemere dieet) või mitut riiki ühendavatest toiduteedest. Viimased seostuvad sageli veinipiirkondadega, mille puhul kasutatakse mõistet terroir ${ }^{3}$ aga ka näiteks hooajaliste köögiviljade või muude söödavate taimede (nt spargel, õunad, seened) maitsmise võimalustega kohalikel festivalidel, taluturgudel, restoranides jne. ${ }^{4}$ Regioon võib niisiis viidata ajaloolis-kultuurilistele toidutootmise ja valmistamise viisidele, hõlmates sealhulgas ka looduslikult kasvavate taimede ja loomade toiduks tarvitamist vastavas piirkonnas. Regionaalne toidukultuur toimib tugeva sümboolse identiteedimarkerina - ennast määratletakse selle kaudu, mida süüakse, kus süüakse ja kelle seltsis süüakse (Leeds-Hurwitz 1993: 92-93). Gastronoomili- 
ne solidaarsustunne võib sealjuures tekkida ka ajutiselt, näiteks suurematel üritustel ja pidustustel.

Toiduregioone ka luuakse, konstrueeritakse, seda teevad näiteks toidutootjad ja tippkokad. Skandinaavia kulinaarne eliit on alates 2005. aastast propageerinud uue Põhjala köögi (New Nordic Cuisine) ideed, rõhutades, et Põhjalale on eripärase kliima ja loodusgeograafia tõttu omased unikaalsed maitsed, sageli tuuakse näiteks looduslikult kasvavad taimed, mille gastronoomilist potentsiaali arendades tuleb toetuda nii traditsioonidele kui ka innovatsioonile. ${ }^{5}$

Tänases ühiskonnas on regionaalne toit ühtlasi kaubamärk. Suurbritannia inimgeograafid David Bell ja Gill Valentine juhivad tähelepanu regionaalsete toodete konstrueeritusele: peaaegu iga toodet, millel on vastava piirkonnaga mingi seos (ükskõik, kas ajalooline või leiutatud), saab müüa kui vastava koha maitse kehastust (Bell \& Valentine 1997: 155). Tööstusliku toidutootmise kontekstis märkame regionaalsust loovaid tähendusi nii spetsiifilistes pakendites kui ka toidutoote kohta käivas loos - see on sümboolne lisaväärtus, mis aitab turul tarbija usaldust võita ja konkurentidega võistelda (Dare jt 2013).

Lisaks sellele on Euroopas nii rahvusriikide (nt Prantsusmaa, Itaalia, Hispaania) kui ka kogu Euroopa Liidu tasandil kasutusel erinevad toidutoodete märgistused, millega rõhutatakse geograafilist ja/või traditsioonilist eripära ja soovitakse kaitsta teatud piirkonna õigusi vastava toidutoote valmistamisel. ${ }^{6}$ Seega võidakse mingi toit või toode kuulutada regiooni omandiks ja legaliseerida selle tootmise monopol. Eestis on küll kasutusel erinevad toidutoodete riiklikud märgistusviisid (nt "Tunnustatud Eesti Maitse", “Tunnustatud Maitse") ja piirkondlikud (nt "Uma Mekk" Võrumaal), aga Euroopa Liidu märgistussüsteemiga veel liitutud pole.

Toidu regionaalsuse rõhutamise sagenemist Euroopas viimastel kümnenditel võib laiemalt vaadelda kui reaktsiooni mitmetele sotsiaalkultuurilistele protsessidele: toidutootmise koondumine suurtootjate kätte, supermarketipõhine toidutarbimine, toidukultuuri jätkuv globaliseerumine ja mcdonaldiseerumine ning sellega kaasnev kulinaarse mitmekesisuse kahanemine. Taasregionaliseerumises nähakse võimalust kultuurilistelt mitmekesisemaks ja jätkusuutlikumaks tootmiseks-tarbimiseks (Donald jt 2010). Piirkonna toitu on hakanud seetõttu taas väärtustama nii professionaalid kui ka teadlikud kodukokad, sest see võimaldab lisaks toidulaua mitmekesistamisele süüa tervislikumalt. Inimeste liikuvuse ja linnastumise tõttu on paigasidemed nõrgenenud. Varem põlvest põlve edasi antud piirkondlikud toiduvalmistamise traditsioonid on asendunud kaubastatud traditsioonidega olgu siis restoranides või turismitaludes. Vastukaaluks võib Euroopas (sealhulgas ka Eestis) näha maaelanike (sageli just linnast maale kolinud haritud noorte) püüet taasavastada ja -toota oma elukoha maitseid. 
Toidu (taas)regionaliseerimine on sageli majanduslik-poliitiliselt laetud retoorika, osa piirkonna arendamise programmidest ja maapiirkondadesse levinud elamusmajandusest (Richards 2012; Bardone 2013). Riiklikes ja kohalike omavalitsuste arenguprogrammides ja turismiarengukavades on oluline koht toidu sidumisel piirkonnaga. Toidu üks eesmärke on piirkonda paremini müüa ja tuua sellesse rohkem tarbijaid, ent laiemaks sihiks on ka vajadus (taas)mõtestada oma kultuurilist identiteeti kiirelt muutuvas sotsiaal-majanduslikus situatsioonis. Kultuuriliste väärtuste arvestamine majanduses on omakorda suunanud regionaalseid arenguprogramme ning toonud lisaraha ja toetusi piirkondade toidukultuuri edendamiseks. See kõik on innustanud ettevõtjaid ja muidu ettevõtlikke inimesi välja tulema üha uute ideedega, kuidas põimida toitu erinevate ürituste (näiteks festivalide) kavasse; pannud otsima kulinaarset omapära ja eristumisvõimalusi; turgutanud loovat tootearendust, mis lõimib traditsioone ja uudseid ideid; ärgitanud võõrastest eeskujudest lähtuvalt "leiutama" ka uusi traditsioone (vrd Hobsbawm \& Ranger 1983), mille ajalugu on veel üsna lühike. Turistidki toidutarbijatena on hakanud väärtustama kohalikku, mahedat, ehedat, looduslikku ja tervislikku. Need on kesksed väärtused, mida tänapäeval heale toidule omistatakse.

Erinevad piirkonnad, olgu linnades või maal, võistlevad omavahel turismisihtkohtadena ja toidul on selliste sihtkohtade kujundamisel ja turundamisel oluline roll. Turismis on läbi aegade peetud oluliseks autentsete kogemuste otsimist. Ehedate, just sellele piirkonnale omaste toiduelamuste saamine võib paljudele turistidele olla oluline lisaväärtus: toitu saab tarbida kohapeal, süües ja toitu ostes saab sotsialiseeruda kohalike inimestega, toidutooteid saab viia kaasa kui kulinaarseid suveniire, reisil söödud toitude pilte saab Facebookis sõpradega jagada jne. Välja on kujunenud terve hulk toiduturismi nišitooteid ja teenuseid: toidufestivalid, retked veinide degusteerimiseks, kohalike kokkade läbiviidavad kokanduskursused jne (Hall jt 2003; Hjalager \& Richards 2002). Euroopas on välja töötatud mitmeid spetsiaalselt toiduturismi propageerivaid programme (nt A Taste of Scotland, ${ }^{7}$ A Taste of West Sweden ${ }^{8}$ ). Toidu kaudu on hea teha piirkonnale reklaami ka seetõttu, et toit hõlmab kõiki meeli, söömine tekitab erinevaid emotsioone ja toitu pakkudes saab seega luua meeldejäävaid elamusi (vrd Pine \& Gilmore 1999). Piirkonnale omaste eriliste toitudega saab köita nii kohalikku kui ka välisturisti. Turistidele toidu müümine motiveerib omakorda piirkondlikke toidutootjaid ja -pakkujaid mõtestama ja ümber mõtestama oma kulinaarset identiteeti (Everett \& Aitchinson 2008).

Nagu mujal Euroopas, on viimastel kümnenditel Eestiski tegeldud toidukultuuri regionaalsuse taasavastamise ja otsimisega. Nii riiklikul kui ka kohalikul tasandil on otsitud vastuseid küsimustele, mis on Eesti toit, kuidas leida kohaliku toidu tarbijaid globaliseerunud turul jne. Veebilehel, mis tutvustab Eesti 
toiduteed nii sise- kui välisturistidele, rõhutatakse: "Eestis on kuus suuremat omanäolist toiduregiooni - Põhja-Eesti; Ida-Eesti; Lõuna-Eesti koos Mulgimaaga; Setumaa; Lääne-Eesti ning saarte piirkond (Hiiumaa, Saaremaa ja Muhumaa) ja lisaks kaks väiksemat toidupiirkonda - Kihnu saar ja Peipsi järve äärsed vanausuliste külad" ning et "iga piirkond on alal hoidnud ajalooliselt välja kujunenud oma eripärased road ja toidukultuuri" (http://www.toidutee. ee/). Seega on liigutud üldistavamast rahvusköögi mudelist mitmekesisema ja piirkondlikkult varieeruva Eesti toidukultuuri kaardistamise suunas. Toiduregioonide eripärade rõhutamine aitab toidu tootmise ja pakkumisega seotud ettevõtjatel üksteisest eristuda. Nagu Skandinaaviaski, edendavad Eestis toidukultuuri tippkokad. Näiteks Dimitri Demjanovi algatatud projekt "Maastik taldrikul 2014-2020" seob ühtsesse arengukavasse Eesti eri piirkondade köögid: Lõuna-Eesti (Võrumaa), seto, mulgi ja vanausuliste köök ning saarte ja rannikuköök. Plaanis on välja töötada kohalikule traditsioonile tuginevad söögid, millega Eesti toidukohad saaksid eristuda nii omavahel kui ka välisriikidest ning taotleda märgised piirkondlikele toidutoodetele (vt Tamm 2013).

Erinevad riiklikud programmid on toetanud kohalikku toitu propageerivaid üritusi ja toidutootjaid, et suureneks nii vastava toidu tootmine kui ka tarbimine. Aastatel 2009-2011 toetati Eestis Euroopa Liidu rahastatud Leader-programmist PRIA vahendusel 157 projekti, mis olid seotud toiduainete töötlemisega ja kogukonnaköökidega (Kõiv \& Lambur 2012: 50). InFacTo (International Food and Activity Tourism Project ${ }^{9}$ ) projekti raames, mida rahastas Euroopa Liidu Interreg IV A programm, on korraldatud koolitusi, seminare ja üritusi, et arendada uusi atraktiivseid välisturistidele suunatud kohaliku toidu ja aktiivse turismi pakkumisi. Regionaalset ja kohalikku toitu toetavate programmide eesmärk on ühelt poolt konkreetsete piirkondade jätkusuutlikkus - et elanikel oleks kohapeal elatusallikad ning et pidurdada väljarännet maapiirkondadest ja väiksematest asulatest. Kui on olemas kriitiline hulk inimesi, kes antud piirkonnas elulaadi edasi kannavad, on ka kohalikul toidukultuuril võimalik püsida. Toetuste ülesandeks on olnud ka tutvustada piirkonna toidukultuuri sise- ja välisturistidele, tõsta ettevõtjate teadlikkust sellele piirkonnale ainuomasest toidukultuurist, mida müües saab suurendada nii külastatavust kui ka tagada kohaliku elu kestmajäämist.

Lisaks sellele on piirkondlike toidutoodete paremaks (ühis)turunduseks ja neile sümboolse lisaväärtuse loomiseks ning laiemalt toidukultuuriga seotud ettevõtluse edendamiseks tekkinud mitmeid kohalikke initsiatiive - Sibulatee; Võru- ja Setumaa toidutee; Lõuna-Eesti toiduvõrgustik, Põhja-Eesti kohalik toit; kaubamärk “Uma Mekk” Võrumaal ja Eestimaa turismitoodete ökoturismi kvaliteedimärgis EHE (ehtne ja huvitav Eesti) jpm. Regionaalse toidukultuuri pärandi väärtustamisega on seotud regionaalsete kokaraamatute väljaand- 
mine viimastel aastatel (Guerrin \& Karu 2014; Mesikäpp \& Kivisalu 2012; Kuvaitseva 2010; Ladõnskaja 2011; Mätas 2009). Eesti eri regioonides võib niisiis märgata nii väljast suunatud kui ka seestpoolt ajendatud huvi jätkuvalt mõtestada oma kulinaarset identiteeti. Mitte ainult turistidele pakkumiseks ja turumajanduses ellu jäämiseks, vaid ka selleks, et tunnetada oma juuri ja kultuurilist kuuluvustunnet.

\section{Allikad ja meetodid}

Uurimuse aluseks on peamiselt osalusvaatluste teel kogutud andmed - autorid (RK ja RS) külastasid mitme aasta jooksul ühtaegu nii uurija kui turisti-ostja rollis artiklis vaatluse all olevaid piirkondi (Saaremaa, Peipsiäär, Jõgeva linn). ${ }^{10}$ Lisaks sellele analüüsisime sekundaarsete allikatena trükiajakirjanduses ja internetis teemakohastel veebilehtedel avaldatud infot.

Välitööde eesmärk oli mõista, kuidas kohalikud omavalitsused ja ettevõtjad konstrueerivad piirkonna toidukultuuri kuvandit, milline on see kuvand, mida turistile erinevates meediakanalites esitatakse, kuidas seostavad ettevõtjad seda kohaliku ajaloo ja traditsioonidega ning kuidas see kuvand ellu rakendub.

Peipsi läänekalda eriilmelise etnilise rühma - vene vanausuliste - toidukultuur, sealhulgas sibulakasvatus, on leidnud kajastamist viimasel ajal arvukates kirjutistes, mille aluseks on olnud intervjuud kohalike elanikega (nt Taavet 2013; Ladõnskaja 2011; Kuvaitseva 2010). Selgub, et sealsed elanikud pole pööranud oma toiduretseptides sibulale sellist rõhku, nagu võiks eeldada. Käesolevas uurimuses ei eristanud me küsitletavaid rahvuse või usu põhjal ega lähtunud algandmete kogumisel süvaintervjuudest, vaid pigem informaalsetest vestlustest sibulamüüjatega, esinedes neis situatsioonides ostja ja turisti rollis. Vestluste käigus küsisime, kust on müüja pärit, kas on hea sibul, kuidas oli saak, palju ostetakse jms.

Saaremaa kohta kogutud osalusvaatluse andmeid täiendasime 2014. aastal läbi viidud etnobotaaniliste välitööde andmetega - intervjueerisime saarlasi looduslike toidu-, maitse- ja ravimtaimede kasutamise, sealhulgas kadaka toiduks tarvitamise teemadel. ${ }^{11}$ Täiendavalt pöörasime Saaremaal tähelepanu mitte ainult sellele, millise mulje saab kohalikust toidust ja toidukultuurist külastaja, vaid uurisime ka, kuivõrd kasutavad kadakat igapäevases toidus kohalikud inimesed.

Jõgeva küüslaugufestivalil osales aastatel 2007-2014 müüjaid ja külastajaid kogu Eestist. Kasutasime välitöödel rohkem osalusvaatlust ja vähem vestlusi, sest ürituse miljöös oli keeruline pikemaid intervjuusid läbi viia. Uurisime 
müüjatelt, kas on hea küüslauk, kust see pärit on, miks just selline hind, kas ostetakse palju, kuidas küüslaugust tooted tehtud on. Seitsmest seni peetud festivalist on autorid (RK, RS) külastanud nelja. ${ }^{12}$

Uuritavad piirkonnad on valinud erinevad strateegiad kohaliku toidu eripära tutvustamiseks konkreetsete toidutaimede kaudu. Kõige intensiivsemalt reklaamis end lühikese ajalooga Jõgeva küüslaugufestival, mille info ilmus nii trükiajakirjanduses kui ka raadios, lisaks suured reklaamtahvlid maanteede ääres. Turistina Saaremaale siirdudes saab kohaliku toidutööstuse toodangut (nt kadakasuitsujuust, kadakaleib jt) osta juba praamilt, kust leiab ka tasuta reklaamlehti Saaremaa toitlustusettevõtete ja kohaliku toidu eripära kohta. Reklaami vastavasisuliste ürituste (nt kadakapäev) kohta tehakse pigem maakonna sees ja elektroonilises meedias kui üleriigiliselt. Kõige vähem torkab silma Peipsi-äärse sibula turundus - kommertsreklaame ei kasutata ja meediakajastusi ilmub siis, kui on ilmnenud mingi probleem. Välireklaamideks on vaid ajutised teede äärde müügiplatside juurde pandud sildid kirjaga "sibul". Ka kohapealseid, kohalike omavalitsuste korraldatud sügisesi sibulalaatasid reklaamitakse väljaspool elektroonilist keskkonda minimaalselt.

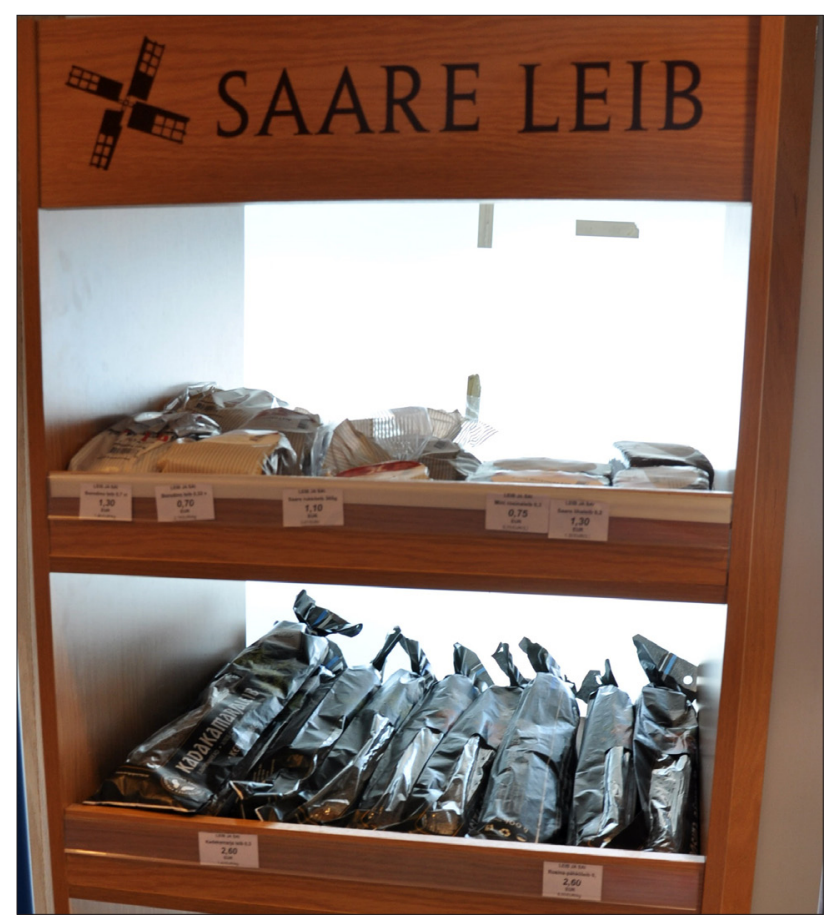

Foto 1. Kadakaleiba (alumisel riiulil) saab Saaremaale siirdudes osta juba praamilt. Renata Sõukandi foto 2012. 


\section{Peipsi-äärne sibul}

Sibulat kasvatatakse tänapäeval maailmas ohtralt ja see on populaarne toidutaim, mida kasutatakse paljude regioonide köökides. Teated sibula toiduks tarvitamisest Eestis pärinevad juba 14. sajandist, mil seda pakuti linnades pidusöömaaegadel (Mänd 2004: 274, 321).

19. sajandil kasvatasid Peipsi läänerannikul sibulaid peamiselt venelased, alles 20. sajandist ka eestlased. Seemet toodi algselt Venemaalt ja Piirissaarest, hiljem kasvatati ise. Sibulakasvatajad müüsid oma saaki nii Tartumaal kui ka mujal Lõuna-Eestis. Veel 1920. aastatel tuli suurem osa Eestis tarbitavast sibulast Peipsi äärest ja Setumaalt. Teistes Eesti piirkondades hakkasid eestlased seda köögivilja laiemalt kasvatama 1930. aastatel, osalt ka köögiviljakasvatuse ja -toitude propageerimise tulemusena (vt Moora 1964; PVL 1923; PVL 1934), mille tõttu vähenes sibulakasvatus Peipsi ääres oluliselt (PVL 1936a; PVL 1936b). Siiski säilis sibulakasvatus Peipsi-äärses piirkonnas olulise kohaliku majandusharuna ka nõukogude ajal, sest sibula kasvatamist soosis sobiv mullaviljakus ja niiskus ning maa vähesusest tingitud traditsiooniline väikepõllundus. Eriti head teenistust saadi sel ajal Venemaa (eeskätt Leningradi) turgudel müümisest. Nii mõnigi kohalik ehitas kurgi-sibula müügist omale sel ajal maja. Eesti iseseisvumisega 1990. aastatel kadus Venemaa turg ja kurgisibula kasvatamise mahud langesid jällegi drastiliselt. ${ }^{13}$ Kuna teenistust enam polnud, hakkas ka elanikkond sealkandis kiiresti vähenema.

Peipsi-äärne sibul on Peipsi läänerannikul välja aretatud sibula sordirühm ja see on ühtlasi esimene Eesti toidutaim, millel on oma kvaliteedikava (Toidukvaliteedikava), mida peab järgima iga tootja, kes väidab, et ta müüb Peipsiäärset sibulat. ${ }^{14}$

Viimastel aastatel on Peipsi-äärne sibulakasvatus madalseisus, nii et selle kohaliku majandusharu säilimiseks on taotletud riiklikke toetusi. 2013. aastal eraldati piirkonna arenguks 348000 eurot (Maaleht 11. juuli 2013), 2014. aastal 273000 eurot (Delfi 21. juuli 2014). Ka suurenenud meediatähelepanu (nt Lukas 2012) on loonud olukorra, kus tarbijad on kogu Eestist hakanud sõitma Peipsi äärde sibulat ostma. Eriti suurte koguste ostmistega on silma paistnud Rae (Heiberg 2012) ja Viimsi vald (Mikovitš 2012), kes oma valla elanike tellimusi koordineerisid. Järsu huvi tõttu tekkis ajuti isegi sibulapuudus (Niitra 2013). Sibula turustamine on seega tänapäevalgi samasugune nagu varasematel aegadel - kohalikud kasvatavad ja turustavad neid kas liiga palju või liiga vähe, mis võib olla tingitud vastavate oskuste või ressursside puudusest või ilmastiku kapriisidest. Möödunud sajandil käisid sibulakasvatajad oma toodangut mööda maad müümas, tänapäeval on müük koondunud küla- ja maanteede äärde. Näiteks suvel mööda Jõhvi-Tartu maanteed sõites võib kohata köögivilja- ja 
kalamüüjaid juba alates Kauksi ristmikust, eriti tihedalt on neid Mustvee ristmikul. Müüjatel oli sibul üks paljudest omakasvatatud köögiviljadest ja oma välitöödel ei kogenud me, et nad ise oleksid suhtunud sellesse kuidagi teisiti kui kurki või kartulisse. Selline teeäärne kauplemine eristab Peipsi-äärset ala muust Eestist, sest nii kontsentreeritult ei kohta köögiviljamüüjaid üheski teises Eesti piirkonnas. ${ }^{15}$

Peipsi-äärsed turismiettevõtted ja köögiviljakasvatajad on loonud oma toodete propageerimiseks ühisturunduse kontseptsiooni Sibulatee, mis hõlmab nii kasvatamise kui ka kohaliku toidu pakkumisega seotud ettevõtteid ja piirkonna muuseume, vaatamisväärtusi, sündmusi ja muud otseselt toidusse mittepuutuvat (www.sibulatee.ee). Sibulateed piiritletakse Emajõest kuni Kallaste linnani. Ettevõtmise eestvedajad rõhutavad, et Sibulatee pakub turistidele võimalust kohtuda kolme kohaliku kultuuriga - vene vanausuliste ja eestlaste talupojakultuuri ning siin kunagi elanud baltisakslaste mõisakultuuriga (Alatskivi loss).

Niisiis on sibula kasvatamise ja müügiga seotud elulaadist saanud turismiatraktsioon, mida tasub mujalt vaatama ja kogema tulla. Siseturistile reklaamitakse just võimalust näha ehedat vanausuliste kultuuri. Näiteks Kolkjas asuvat Pauli talu ja tema peremeest Konstantini, kes külalistega räägib nii vene kui ka eesti keeles, tutvustatakse nii:

Kostja juures näete vanausuliste traditsioonilisi sibulakasvatuse võtteid ning peremees räägib kuidas vanasti sibulaid kasvatati ja kuidas tänapäeval kohalikud siiruviirulisi aiasaadusi maha panevad, üles võtavad ja müüvad. Ehk selline tubli tund aega sibulakasvatusse ja vanausuliste traditsioonidesse juhatavat giidijuttu. Eriliseks teeb Kostja veel tema oskus võrke punuda ja huvilistele läbi viia võrgupunumise õpitubasid. Ja peamine - siinne perenaine teeb suussulavaid sibulapirukaid! Kui Sa tead, et oled siiakanti teel, siis helista Kostjale ette ja telli pirukad ette. Need on seda väärt! (http://sibulatee.ee/uus-liige-pauli-talu/)

Söögikohti, kus serveeritakse kohalikest saadustest (kalast ja sibulast) toitusid, võib leida Peipsi ääres mitmeid. Tuntum neist on Kolkjas asuv kala-sibularestoran, mille menüüs on lisaks teistele traditsioonilistele roogadele sibulasalat ja -supp (Menüü_2014). Söögikoha interjööris eksponeeritakse ohtralt, kohati ülepakutultki, piirkonnale iseloomulikke etnograafilisi ja religioosseid esemeid, mis peaksid justkui tugevdama seost kohaliku toidu ja kultuuriga. Sibulateele jäävates paikades korraldatakse aastaringselt sündmusi, mille kohta võib infot leida vastavalt veebilehelt - otseselt sibulaga on seotud näiteks augusti lõpus Kallaste linna korraldatav sibula- ja kalalaat ning septembris Varnja külas sibula- ja jõhvikalaat. 


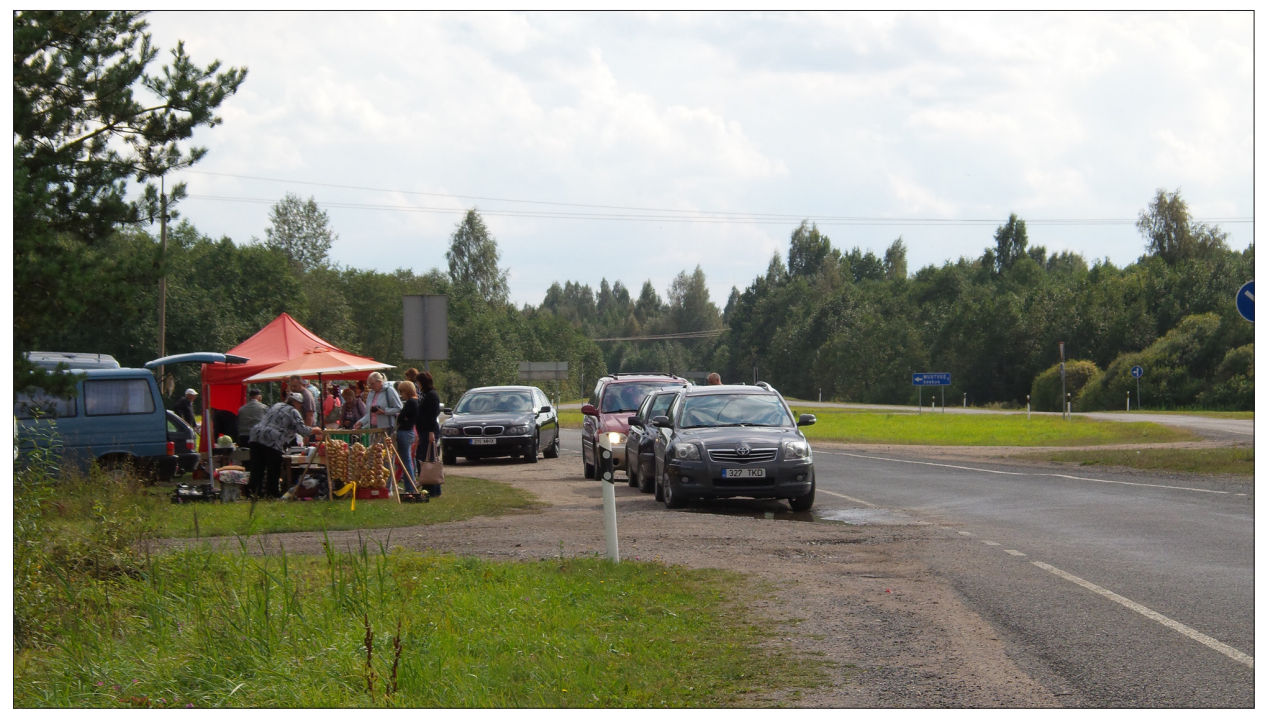

Foto 2. Köögiviljamüüjad ja -ostjad Jõhvi-Tartu maantee ja Mustvee tee ristmikul 2014. aasta augustis. Renata Sõukandi foto.

Sibulateest lõuna poole jäävad samuti vanad sibulakasvatuse piirkonnad ajaloolisel Setumaal. Tuntuim üritus on Mikitamäe valla korraldatav Lüübnitsa sibula- ja kalalaat, mis toimub enamasti augusti eelviimasel nädalavahetusel (Kauplemistingimused_2014). Kuigi Lüübnitsa ei kuulu Sibulatee koosseisu, jääb see Peipsi-äärse sibula toidukvaliteedikava piiridesse. Samas ei hõlma Sibulatee ega toidukvaliteedikava kumbki peamiselt eestlastega asustatud ala Raja külast kuni Kauksini, mida saab sisuliselt samuti nimetada Peipsi-äärseks sibulakasvatuspiirkonnaks, sest turist ega kohalik köögiviljakasvataja ei järgi kunstlikke piire ja ostab/müüb Peipsi-äärset sibulat ka väljaspool Sibulateed.

Kokkuvõtvalt võib öelda, et Peipsi-äärne sibul on täna üks enim meedias tähelepanu (mitte reklaami) saanud ning tihedamini kohaliku kultuuri ja loodusega seotud regionaalne sümbol-toidutaim. Sibulakasvatus on kohalikele elanikele oluline tegevusala, kuigi selle tähtsus on kahanenud. Ajaloolisi tavasid, sealhulgas toidukultuuriga seotud kombeid ja oskusi, peetakse kohalike seas au sees ja soovitakse neid tutvustada ka turistidele. Piirkonna sibulakasvatuse argipäevas säilinud traditsioonid annavad kohalikule sibulale kui turismimagnetile eheduse ja autentsuse. Sibula ja sellest valmistatud toitude kaudu saab Peipsiveere piirkonda tervikuna paremini turistile tutvustada, isegi siis, kui turist sibulat suurtes kogustes kaasa ei osta. 


\section{Saaremaine kadakas}

Saaremaa ajalooliste juurtega toidutoodetest on tuntuimad kalatooted, õlu ja leib. Kadakas, mida on aastakümneid kasutatud turistidele mõeldud (tarbe) suveniiride materjalina, on viimastel aastatel üha enam pälvinud tähelepanu ka toidutaimena. Kadakat peetakse õigusega Saaremaa sümboliks - Saaremaa on kõige kadakasem piirkond Eestis. Koos Läänemaaga moodustab see kokku 75\% kogu Eesti kadakakasvualast (Kadakas_2014). Turistidele mõeldud kodulehel märgitakse, et kadakapuidust köögitarbeesemed peaks toidule edasi andma "erilise väe" (Saaremaa_2014). Kadaka tuntuimateks toiduainena kasutust leidnud saadusteks on marjad (botaaniliselt küll käbid), millega maitsestatakse toite ja jooke. Kadakamarju saab tänapäeval osta ka poodidest ja laatadelt, ehkki seal müüakse peamiselt Saksamaalt imporditud marju.

Saaremaa toidukultuuriga tutvumine eeldab erinevalt Peipsiveerest mitmepäevast kohalolekut. Saarlastel pole kombeks müüa oma aiasaadusi ja suitsutatud-kuivatatud kala suvel teeäärsetel ajutistel müügiplatsidel. Vaid kohalikel saadustel või retseptidel põhinevaid toite pakkuvaid söögikohti, nagu Peipsi ääres, ei õnnestunud autoritel välitööde käigus leida. Siiski sai Lümanda söögimajas maitsta kadakamarjadega marineeritud heeringat, mis on üks Saaremaa maitse loomise näide (Menüü2_2014). ${ }^{16}$ Kadakamarjadega maitsestatud või kadakaokstega suitsutatud roogasid võib aga leida mujal Eestis nii mõneski restoranis, mis tähendab, et kadakas sümboliseerib pigem Eesti kööki tervikuna, mitte ainult Saaremaad.

Järgnevalt võrdleme kadakamarjade ja -okste kasutamist endistel aegadel ja tänapäeval. Tugineme seejuures etnograafilistele allikatele (Moora 1982, 1984; Viires 2000) ja oma välitöödel kogutud andmetele. Ilmneb, et kadakamarju on niisama söödud nii varasematel aegadel (19. sajandil ja 20. sajandi alguses) kui ka praegu. Pöide kihelkonnas on kadakamarja taari tehtud varem nii, et purustatud marjad lisati taarijahule, siis hautati ja lasti hapneda (Moora 1984: 378/9), nüüdki saime sealt kihelkonnast teate, et informandi vanaisa olevat teinud kadakamarja-rikastel aastatel kadakataari. Marjad songiti puruks ja pandi ôlleteost järele jäänud raba peale, kallati kuuma veega üle ning lasti paar päeva haududa ja hapneda. Läänemaalt, Hanilast, on teada ka kadakamarjade panemist leiva sisse (Viires 2000: 102).

Kadakaokstega on varem suitsutatud meeldiva maitse saamiseks liha (Viires 2000: 99) ning see komme on liha ja kala suitsutamisel levinud ka tänapäeval. Kui kadakaokstega on varem maitsestatud kääritatud ja hapendatud kasemahla (Moora 1982: 299), siis nüüd saime vaid üksikteate sellest, et kasemahla hapendamisel on lisatud kadakamarju, et jook ei läheks venima ja halvaks. 
Raivo Kalle, Ester Bardone, Renata Sõukand

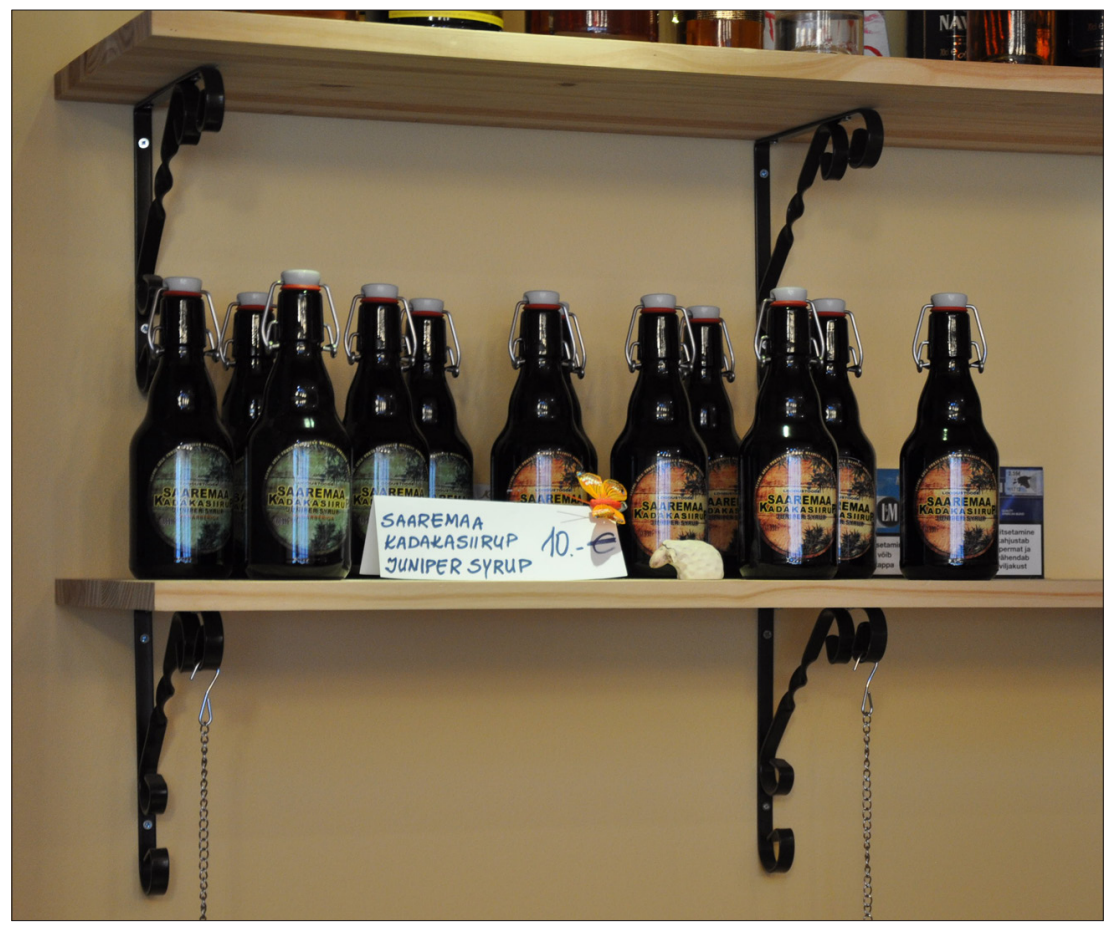

Foto 3. Saaremaalt võib soovija suveniiri asemel kaasa osta ka kadakasiirupit. Renata Sõukandi foto 2012.

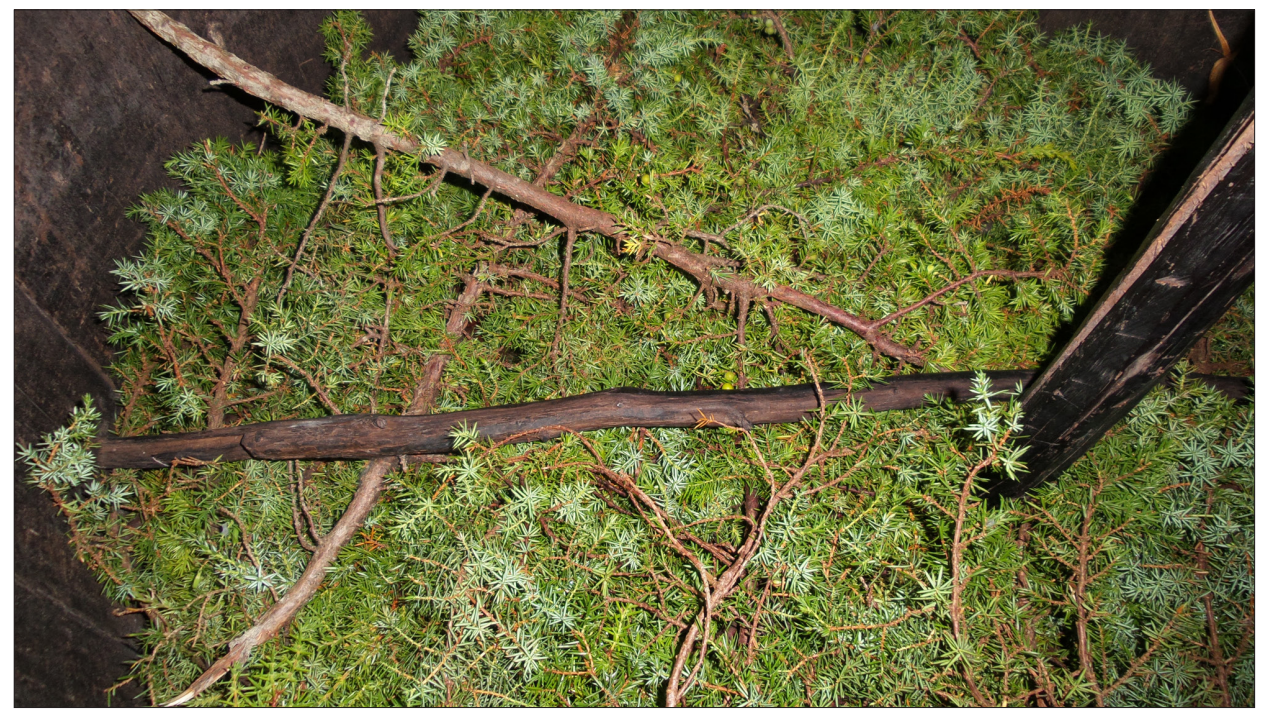

Foto 4. Kadakaokstest soova koduõlle teos Jaani kihelkonnas 2014. aasta juulis. Renata Sõukandi foto. 
Kogu Eestis oli varem tuntud kadakaokste kasutamine koduõlleteos nii tõrrefiltri tegemisel kui ka marjarikaste okste keeduvee lisamine õllele (Viires 2000: 100), samu tegutsemisviise tuntakse Saaremaal laialt ka nüüd. Huvitav on sealjuures, et kadakaoksi hakati koduõlles tõrrefiltri (soova) tegemiseks (rukkiõlgede asemel) kasutama olude sunnil, põhjuseks rukkikasvatuse vähenemine ja kombainide tulek, milles hekseldatud kõrred ei sobinud enam soovaks.

Puuduvad varased kirjalikud allikad selle kohta, nagu oleks eestlased kasutanud kadakamarju lihatoitude maitsestamiseks. Arvatavasti on selline komme levinud kokaraamatute kaudu (nt Koor 1889; Pihlik 2006; Suitsu 2009 jt), milles soovitatakse kadakamarju lamba-, uluki-ja rasvasest veiselihast toitude maitsestamiseks. Selgus, et täna kadakamarju igapäevaste toitude valmistamisel enamasti ei kasutata, kui, siis lisatakse neid jõulupraele. Siiski ütlesid kokaharidusega või lambakasvatajast naised, et kasutavad kadakamarju lambaprae valmistamisel ja jahindusega seotud mehed mainisid ulukilihast (metssea-, hirve-, põdra-, vähem metskitseliha) toitude maitsestamist. Üksikteate põhjal kasutati kadakamarju ka sealiha soolamisel parema maitse saamiseks.

Kadakamarjade lisamine viinale koduse napsi valmistamiseks on tuntud kogu Eestis (Kalle \& Sõukand 2013: 224). Ka Saaremaalt saime selle kohta kinnitust. Samas öeldi, et sellist jooki hakati tegema kirjandusest või meediast saadud teabe põhjal. Kadakamarjadega maitsestatud viina ehk džinni toodetakse Eestis ka tööstuslikult.

Saaremaa toiduainetööstustes on nii varasematel aegadel kui ka tänapäeval kasutatud kadakat toidutoodetele piirkondliku maitse ja sümboolse lisaväärtuse andmiseks. Näiteks ettevõte Saare Õlu ja tema eelkäijad tootsid Eesti NSVs ja ka Eesti Vabariigi ajal (kuni tehase sulgemiseni 1999. aastal) marki "Kadaka õlu"17. Tänaseks on üheks tuntumaks tooteks kujunenud Saaremaa piimatööstuses toodetav kadakaga suitsutatud juust (Saaremaajuust_2014), mis on saanud nii Tunnustatud Eesti Maitse kui ka Tunnustatud Maitse märgise. Kuna nii kadakaõlu kui ka kadakaokstega suitsutamine on olnud saarlaste hulgas tuntud, eksisteerib neil toodetel ajalooline seos piirkonna rahvalike kulinaarsete traditsioonidega.

Kadakamaitselised toiduained on siiski kohalikus toiduainetööstuses alles viimase aastakümne mood ja mõnel tootel pole üldse saaremaist või isegi Eestile omast algupära. Näiteks Mustajala vallas paiknev ettevõte Mustjala Mustard pakub oma muude sinepite hulgas ka kadakamarjasinepit (Sinep_2014). Ka Saaremaa mahetootjaid ühendav kaubamärk Saare Mahe tutvustab oma kodulehel (saaremahe.ee/tootearendus/): "uued, kuid samas vanu traditsioone kandvad retseptid hoidiste, teravilja- ja lihatoodete valdkonnas", mis on välja töötatud koos tootjate, töötlejate ja turundusekspertidega. Neid soovitatakse 
Saaremaa väiketootjatele valmistamiseks, teiste seas näiteks maitsesool kadakamarjadega ja kadakaleib, mille retsepti üks koostisosa on kadakatõmmis, samas ei täpsustata, kuidas seda tõmmist teha või kust seda saada (Leib_2014). Ka väljaspool Saaremaad asuvad ettevõtted reklaamivad oma kadakatooteid sageli saaremaiste maitsetena. Näiteks Tallinnas asuv eksklusiivseid toite pakkuv Gourmet Club kirjeldab oma kadakamarjaleiba kui "saaremaiselt mõnusat ja tervislikku" (Leib2_2014), seda pakutakse ka Eestit külastavatele välisturistidele toidusuveniirina (nt Tallinna lennujaamas). Eesti suveniirtoiduks võib pidada ka Põlvamaal asuvate Kõlleste kommimeistrite kadakamarjadega käsitööšokolaadi.

Sarnaselt Peipsi-äärsele piirkonnale, kus on hakatud korraldama sibulalaatasid rohkem turistide ligimeelitamiseks, on ka Saaremaal, Leedri külas tekkinud kadakapäev, mis toimus 2014. aastal teist korda ja oli suunatud enamasti väljast tulevatele tarbijatele. Sealgi pakuti erinevaid toite ja jooke milles oli kasutatud kadakat (Laine 2014). Ürituse eestvedajaks on samas külas aastast 2011 kadakasiirupit valmistav ettevõte A-Orbu. Kadakasiirupit tehakse peamiselt kadakavõrsete vees kuumutamise teel, ja selle uudistoote võtsid ostjad kohe suure huviga vastu (Lember 2011; Kallas 2013), 2014. aastast tehakse koostöös Rapla marmelaadimeistritega ka kadakasiirupist marmelaadikomme (Kalmus 2014). Siiski võib siirupi algne idee pärineda mandrilt, kus olevat tehtud kuusevõrse-jooki, või ka põhjanaabritelt. ${ }^{18}$ Oma toote paremaks müümiseks ja kohaliku piirkonnaga sidumiseks on kadakasiirupi tootjad välja mõeldud legendi roosapõsksest siirupiemandast, kes kadakate keskel väsimatult tööd tegi, ja kinnitavad, et ka saarlasi saab võrrelda kadakaga, kuna nad on "visad, elujõulised, jonnakad ja terve jumega" (Legend_2014). Kadakasiirupi tootjad toonitavad veel, et "puhtalt ja loodust säästes käsitsi korjatud tooraine pärineb Leedri külast, Saaremaalt", rõhutades nii kohaliku ja ökoloogilise toidu väärtusi. Kadakasiirup on hea näide, kuidas tootjad loovad lugusid, mis omistavad tootele kohalikku algupära, ja püüavad leida uusi väljundeid meelelahutust pakkuvate müügipäevade abil.

Kokkuvõttes saab väita, et saarlaste kodune kadaka kasutamine toiduvalmistamisel ei erine mandril elavate eestlaste omast, piiranguid seab vaid kadakate-marjade kättesaadavus. Samas on väike- ja suurtootjad Saaremaal (erinevalt mandri ettevõtetest) hakanud kadakat kasutama uuenduslikes toodetes, mille turustamisel lõimitakse folkloorseid traditsioone väljamõeldud lugudega ja püütakse leida uusi nišiturgusid. Kadakaga valmistatud toidutooteid müüakse turistidele kulinaarsete suveniiridena ka mujal Eestis, ent Saaremaal toetab kohalik loodus kadaka tarbimist enam ning side regionaalse toidu ja kultuuri vahel mõjub usutavamana. 


\section{Jõgeva küüslaugufestival}

Kui Peipsi-äärsel sibulakasvatusel on ajalugu üle sajandi ja kadakas on levinud taim Saaremaa looduses, siis Jõgeva linna ja küüslaugu vahel on otsest seost näha keerulisem, ehkki 2014. aastal toimus seal seitsmendat aastat järjest üritus, mida reklaamiti kaubamärgina “Jõgeva Küüslaugu Festival”. Loomaks oma kohaturunduslikku lugu, valiti külmapealinna Jõgevat, kus registreeriti 1940. aastal Eesti madalaim temperatuur $\left(-43,5^{\circ} \mathrm{C}\right)$, esindama küüslauk kui tuntud kodune külmetushaiguste ravim. Teisalt pole ürituse korraldajad eitanud, et eeskuju saadi ka välismaalt. Väljaspool Eestit on küüslaugufestivalide korraldamine populaarne, eriti Ameerika Ühendriikides, näiteks Gilroy linnas peeti 2014. aastal küüslaugufestivali juba 36. korda. Samalaadseid üritusi toimub ka Euroopas - Itaalias, Suurbritannias, Prantsusmaal ja teistes riikides. ${ }^{19}$ Näiteks soomlastelgi on pikaajalised traditsioonid pidada neid erinevates linnades (nt Keraval ja Oulus). Küüslaugust on seega saanud kohaturunduslik vahend ja sümbol, mille puhul pole tingimata olulised just selles piirkonnas kasvatatud köögivilja maitseomadused, sest müüjaid võib tulla mujaltki, vaid lisaks ka mängulisus, loovus ja meelelahutus (vrd Adema 2009: 80).

Eestlaste toidukultuuris pole küüslauk ajalooliselt nii levinud nagu näiteks Vahemeremaade köökides. Linnarahvas ja baltisakslased kasutasid küüslauku küll juba 16. sajandist peotoitudes (Mänd 2004: 326, 341), aga eesti talupojad ei võtnud seda pikka aega omaks. Veel 20. sajandi alguse eestikeelses köögiviljakasvatuse õpperaamatus öeldakse, et "küüslauku läheb harilikult vähe tarvis; sellepärast on väikses majapidamises mõnest ainsast taimest küllalt" (Böttner 1913: 154). Ka möödunud sajandi alguse kokaraamatutes pole küüslauku toitude maitsestamiseks peaaegu üldse soovitatud. 1930. aastatest võib leida nõuandeid lisada küüslauku erinevatele lihavorstidele (Pagland 1933). Pärimuseski leidub teateid, et küüslaugu maitset tunti esmakordselt just vorsti süües. Samas kasutasid siin elavad teised rahvad tol ajal küüslauku rohkesti, näiteks juudid, kes seda köögivilja üsna palju sõid ja paiguti kutsutigi küüslauku seepärast juudisibulaks. Nõukogude ajal laienes küüslaugu kasutamine tõenäoliselt massiliselt sisserännanute mõjutusena ja hakati kasutama lisaks vorstidele ka lihatoitude ja suppide maitsestajana. Ka eesti rahvameditsiinis võeti küüslauk kasutusele alles 1920. aastatel ja 21. sajandiks kujunes sellest juba üks populaarsemaid ravimtaimi (Sõukand \& Kalle 2011). Viimastel kümnenditel on ka eestlased hakanud küüslauku kulinaarse teabe leviku, kokaraamatute ja reisikogemuste mõjul toiduvalmistamisel julgemalt tarvitama.

Kuna küüslaugu puhul tugevad piirkondlikud kulinaarsed traditsioonid puuduvad, pakkus Jõgeva küüslaugufestivalil osalenud tootjatele ja -ettevõtjatele võimalust panna oma fantaasia proovile ning üllatada külastajaid 


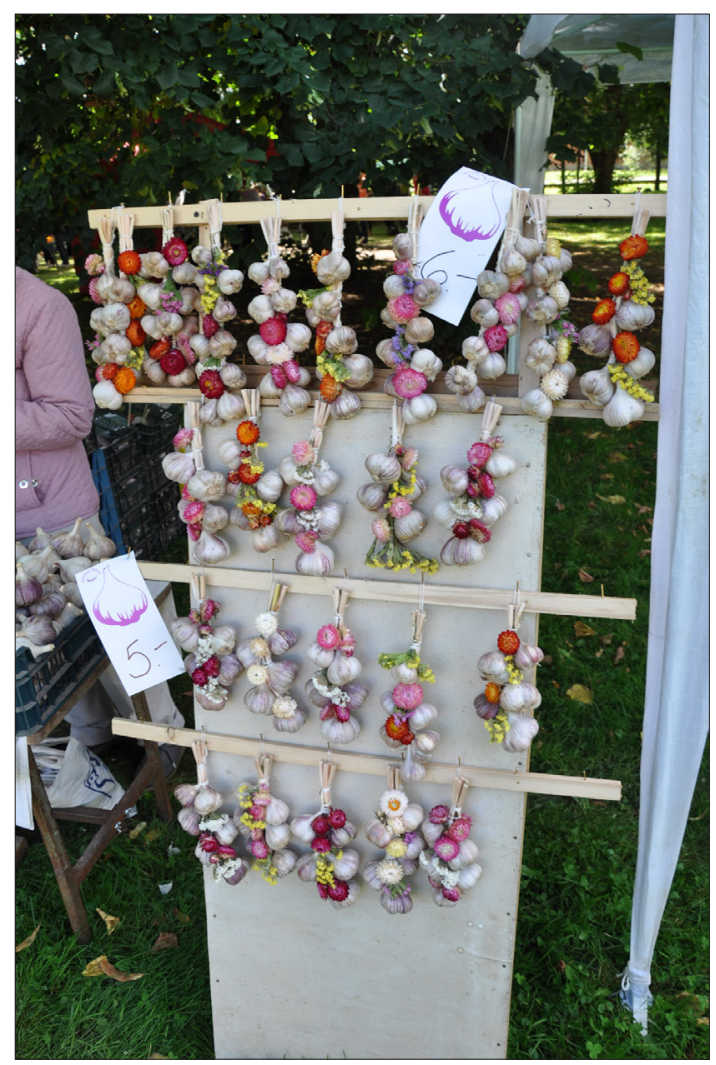

Foto 5. Vanikusse põimitud kü̈̈slaugud paeluvad pilku nii festivalikaubana kui ka koduköögis dekoratiivse elemendina. Raivo Kalle foto 2014.

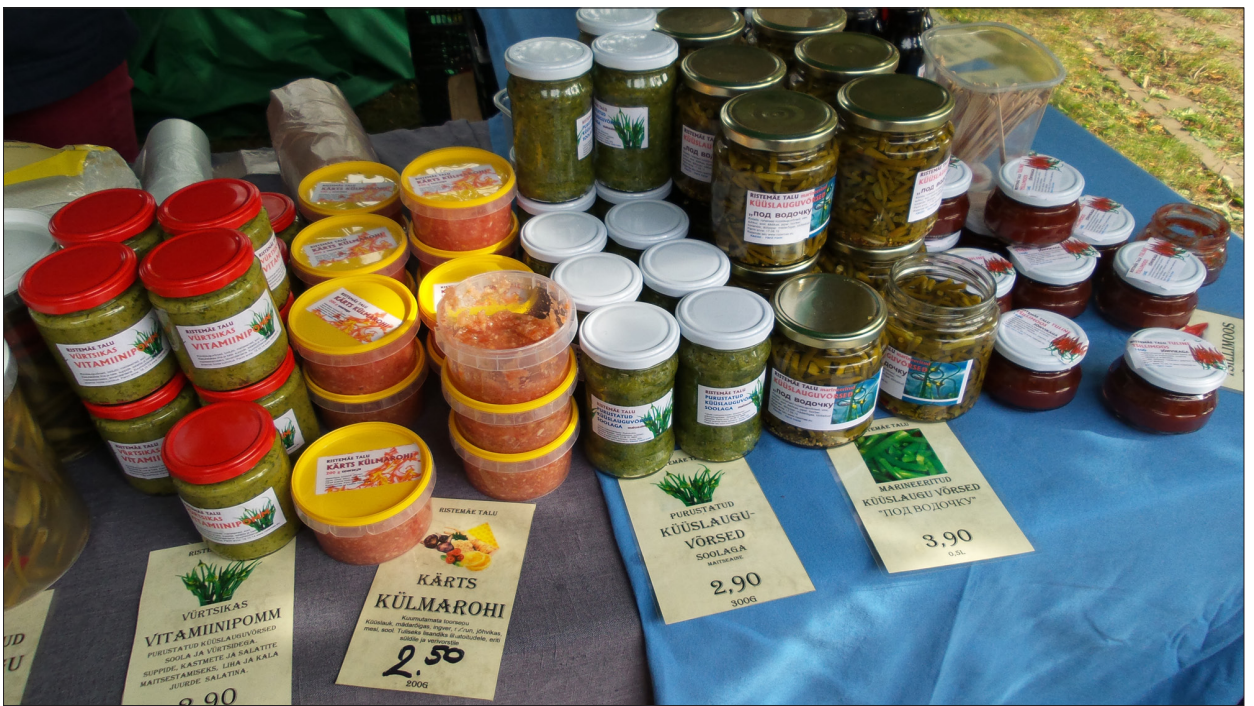

Foto 6. Jõgeva küüslaugufestivalilt võis ostja soetada endale ka kõikvõimalikke küüslauguhoidiseid. Raivo Kalle foto 2014. 
erinevate küüslaugumaitseliste toitudega. Küüslaugu teemast on linn olnud haaratud juba festivalile eelnevatel päevadel - 2012. aastal sai näiteks kahes kohalikus toidukohas juba viis päeva enne üritust valida menüüst mitmeid küüslauguga maitsestatud toite, mida seal muidu ei pakuta. 2014. aastal, nagu varasematel kordadelgi, võis festivalil maitsta küüslaugujäätist, -šokolaadi, -komme, -suhkruvatti, -kohvi, -õlut, -suppi, -moosi, -vorsti, -juustu, -viina, röstitud küüslauku, konserveeritud küüslauku ja hapendatud küüslauguvarsi. Niisiis kasutati küüslauku üsna ebatavalistes maitsekombinatsioonides, eriti magusates toidutoodetes. Ka siin on eeskuju võetud mujal maailmas toimuvatest küüslaugufestivalidest, kus näiteks jäätis on üks oluline müügiartikkel. Viimasel ajal müüki tulnud hapendatud/soolatud küüslauguvarte algne idee pärineb samuti väljastpoolt Eestit. Üllatusmoment ja uudsed maitsed võivad toiduturismis luua küll meeldejääva elamuse, aga seda nii positiivses kui ka negatiivses mõttes - kõik tarbijad ja turistid ei pruugi olla altid uusi maitseid proovima.

Küüslaugumüüjate kõrval leidus Jõgeval palju ka muude köögiviljade ja toidukaupade müüjaid, nagu teistelgi suvelõpu laatadel. Kui veel kolm-neli aastat tagasi paistsid ainult küüslauku müüvad letid selgelt silma ja iga aastaga suurenes just Jõgeva maakonnast pärit kasvatajate hulk, siis 2014. aasta festivalil oli üksnes küüslauku pakkuvate lettide arv marginaalne. Nende asemele olid tulnud kõikvõimalikud muud kaubad ning suure ala võtsid enda alla toitlustajad. Ümbruskonnast olid esindatud vaid üksikud suured küüslaugukasvatajad. Mustvee teeristil Tartu maantee ääres ühe küüslaugumüüjaga vesteldes selgus, et enam ei taheta Jõgevale müüma minna, sest seal on konkurents liiga tihe. Sellegipoolest võib festivali mõjuks piirkonna majandustegevusele pidada kasvõi ajutist küüslaugu kasvatamise suurenemist, mis loodetavasti jätkub ka tulevikus.

Laatadele iseloomulikult oli Jõgeva küüslaugufestivalil palju meelelahutuslikke elemente, eriti lastele suunatud atraktsioone: kuivadest põhupakkidest tehtud omapärased mängunurgad, suur aedik talu- ja eksootiliste loomadega. Teistest suvelõpuüritustest eristasid seda temaatilised võistlused: "Kauneim kaupleja", "Kauneim küüslaugukübar" ja "Eesti suurim küüslauk”. 2014. aastal kutsuti kuulama aiandusteadlase Priit Põldma loengut küüslaugust. Suurima küüslaugu konkursi tõttu on üha rohkem müüjaid toonud festivalile väga suuri liitsibulaid. Suuri küüslaugusibulaid on rikkaliku saagi tõttu kasumlikum toota, seepärast müüvadki neid enamasti suurtootjad. Potipõllumehed, kes kasvatavad ilma väetisteta, oma normaalsuuruses küüslauke enam festivalile müüma ei tule. Uued taliküüslaugud on lisaks suurusele ka tunduvalt vängema maitsega, mille tõttu on autoritele välitöödel korduvalt öeldud, et endiseid väiksemaid, mahedamaid ja meie tingimustes talvel toas paremini säilivaid 
suviküüslauke igatsetakse nüüd taga, sest nende maitsega ja toidu tegemiseks sobiva suurusega ollakse harjunud. Ka küüslauguvanikute kaunistamine sügismarjade, lillede ja viljapeadega võib osalt olla ajendatud Jõgeva festivali konkursist, kust see on levinud ka teistele üritustele (müüjad on enamasti laatadel samad ja müümata jäänud kaup viiakse müügiks järgmisse kohta). Selliste vanikute puhul ei määra hinda niivõrd küüslaugu maitseomadused kuivõrd müüja/tootja kunstimeel ja käsitööoskus. Mõistagi on need kallimad kui kaunistamata vanikud ja lahtine küüslauk.

Jõgeva küüslaugufestivali suurimaks miinuseks võib pidada küüslaugu ja teiste köögiviljade kõrgeid hindasid võrreldes muude müügikohtadega või ka näiteks samal ajal toimunud Lüübnitsa sibulalaadaga, mille taga on kohalik omavalitsus. Festival muutus aastatega küüslaugu ostmise kohast pigem meelelahutusürituseks. Samas ei soosinud püsikülastajate tekkimist kõrged sissepääsuhinnad, mille kohta leiab nurinat üritusest kirjutava elektroonilise meedia kommentaariumides.

2014. aasta sügisel teatas festivali peakorraldaja Aimar Pihlak, et üritus toimus Jõgeva linnas viimast korda, kuna see kasvas liiga suureks ja kultuuri-

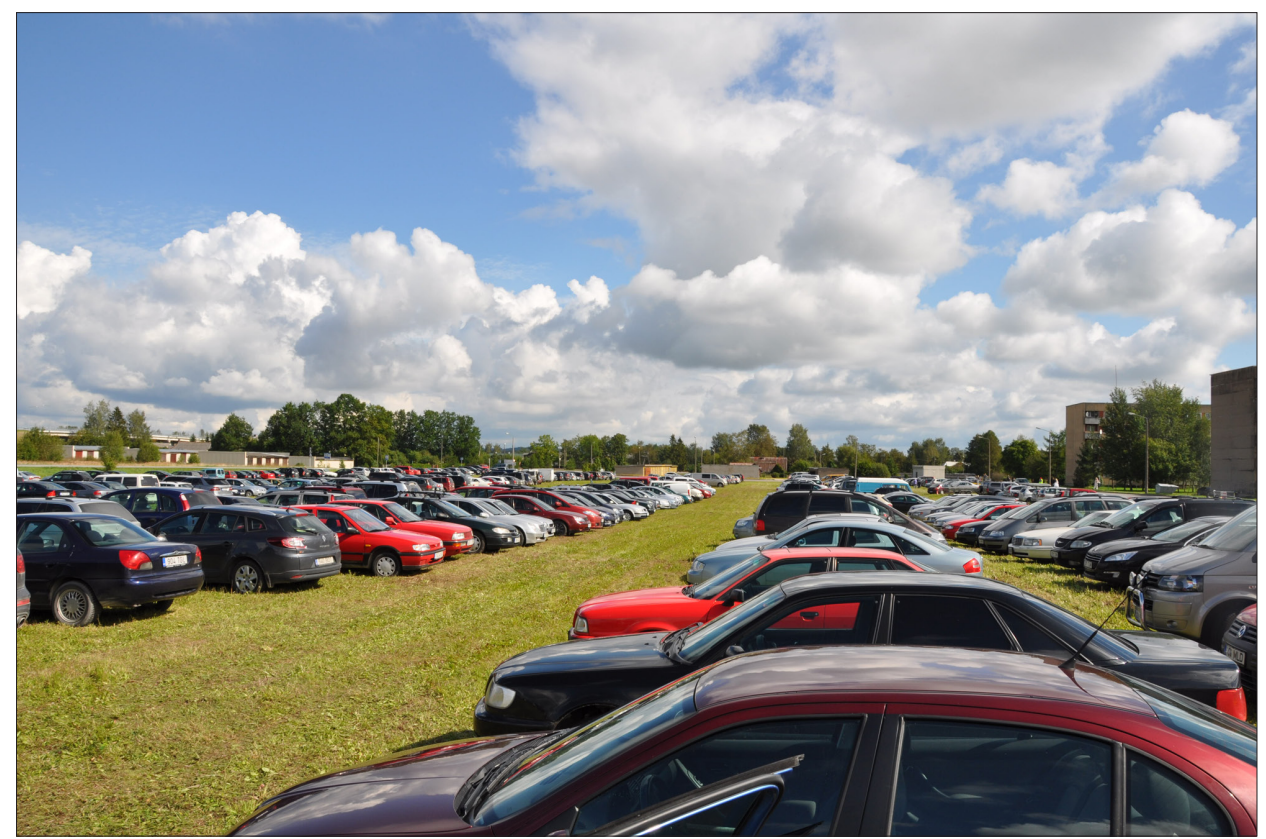

Foto 7. Kü̈̈slaugufestivali aegne Jõgeva - autod ummistavad linnaäärse ajutise parkla, sest festival ajendas Jõgevat väisama ka neid, kes muidu sellesse väikelinna ei satu. Raivo Kalle foto 2014. 
keskuse park, mis oli algusest peale olnud ebasobiv, jäi väikeseks. Tema sõnul on festivali korraldamiseks tulnud teha liiga palju kulutusi ja linn pole neid piisavalt toetanud, vaid küsinud isegi kultuurikeskuse ruumide eest renti, samas kui üritus on loonud Jõgevale positiivse imago. Pihlak väitis: "Meil ei ole aega oodata, millal kohalik omavalitsus ja linnaelanik selle sündmuse omaks võtavad" (Alev 2014). Jõgeva abilinnapea Raivo Meitus möönis omakorda, et linn oleks võinud teatud aspektides korraldajatele rohkem vastu tulla, ent neil napib raha selliste mastaapidega üritusele spetsiaalse keskkonna väljaehitamiseks ja vahendite muretsemiseks (Alev 2014). Lisaks kohaliku omavalitsuse ja ürituse korraldajate vahelisele huvide konfliktile mõjutas festivali korraldamise lõpetamist Jõgeval nähtavasti ka 2014. aasta pärastlõunane tugev paduvihm, mis nii müüjatele kui korraldajatele suurt kahju tegi. Küüslaugufestivali uueks toimumiskohaks on valitud Eesti Põllumajandusmuuseum Tartumaal, Ülenurmel. See on kindlasti sobiv keskkond, ent suvel-sügisel korraldatakse seal peaaegu igal nädalalõpul erinevaid üritusi, nii et küüslaugust saab vaid üks teema paljude seas.

Küüslaugufestivali lõpp Jõgeval tõstatab mitmeid küsimusi festivali seotusest kohaliku elu ja kultuuriga, samuti korraldajate esialgsetest kavatsustest kas laienemine oli kavas algusest peale või taheti pigem kujundada Jõgevale omane temaatiline, kindlate raamidega üritus. Võimalik, et nii-öelda tühjale kohale tekitatud turundusliku eesmärgiga festivali püsimajäämine ongi problemaatilisem kui ajaloolist tausta arvestavate ettevõtmiste kestvus. Kindlasti oli Jõgeva festivali külastajate seas inimesi, kes muul ajal Jõgeva linna ei satugi ja seda tüüpi festivali eesmärk võiks muuhulgas olla ka püüd tutvustada turismisihtkohtadena vähemtuntud paiku Eestis.

\section{Arutelu ja kokkuvõte}

Kolm valitud toidutaime illustreerivad ilmekalt nende kui sümboolse kulinaarse identiteedimarkeri kasutamise võimalusi ja probleemistikku.

Peipsi-äärse sibula puhul võib rääkida piirkonna taimekasvatuse ja toidutraditsioonide väärtustamisest, aga ka sibula kaubastamisest. Kusjuures ajalooline traditsioon on iseenesest lisaväärtus, ja seda on ka kergem müüa autentsena. Erinevus võrreldes kahe teise näitega on selles, et Peipsi kandis ei turustata niivõrd sibulast toidutooteid ja roogasid kuivõrd toorainet ennast. Peipsi-äärse sibula puhul on oluline tulevikku ulatuv probleem läbi aegade olnud tugevate ettevõtjate ja äriplaanide puudus. Küsimuseks jääb, kes ja kuidas peaks toetama traditsioonilist väikemajapidamistele rajatud sibula- 
kasvatust, kui kohalikud kasvatajad-väiketootjad vananevad ja nende ring jääb järjest väiksemaks. Kuigi erinevate riiklike programmide vahendusel on Peipsi-äärset piirkonda toetatud, on müügitulemused jäänud tagasihoidlikuks. Sibulatee ei lahenda paraku piirkondliku sibula turustamise ja kasutamisega seotud laiemaid probleeme.

Saaremaa kadakas pakub huvitava näite loodusliku ja kultuurilise ning traditsioonide ja innovatsiooni põimumisest ühe toidutaime näitel. Sidusust regiooni ja traditsioonide vahel aitab luua see, et kadakas on aastasadu Saaremaal kasvanud, kasvab praegugi ning seda on ka varem toidutaimena kasutatud. Tänapäeval antakse kadaka abil toidule regionaalne mekk, lisaks varem tuntud kulinaarsele kasutusele otsitakse uudseid tootearendusi, mille hea näide on kadakasiirup. Kindlasti ei piisa saaremaiste toidutoodete müügieduks ainult kadaka lisamisest, pealegi kasutavad kadakamarju lisandina ja Eestile omaste toitude või toidusuveniiride valmistajana ka teised ettevõtjad. Niisiis võidakse ühe kindla regiooniga seostuvat toidutoodet turustada ka mujal ning sõltuvalt kontekstist võivad kadakamaitselised tooted esindada nii Saaremaad kulinaarse piirkonnana kui ka tervet Eestit. Saaremaa trump kadakamaiguliste toitude turul on kohalik loodus ja kultuur, eriti aga kohaspetsiifilised lood, mida toidutootjad võiksid turunduses julgemaltki kasutada.

Jõgeva küüslaugufestival on kahe eelnevaga võrreldes arvatavasti kõige uudsem näide, mille puhul regionaalne (kulinaarne) identiteet oli tekitatud teadlikult, kombineerides mänguliselt mitmeid eri päritolu kultuurielemente. Nii küüslaugu kasvatamisel kui ka kasutamisel puudub Eestis ajalooline traditsioon. Seega on tegu selgelt "leiutatud traditsiooniga" (Hobsbawm \& Ranger 1983), mis seostub samalaadsete võrdlemisi lühikese ajalooga üritustega mujal maailmas, kus püütakse ühe toidu ja toidufestivali abil mingit piirkonda propageerida. Festival paigutub niisiis pigem kohaturunduse konteksti, järgides põhimõtet, et igal linnal peab olema oma lugu ja tooted, millega turistide tähelepanu võita. Küüslauk oli Jõgeva sümboliks valitud võrdlemisi juhuslikult. Festivali korraldamise lõpp Jõgeval kinnitab, et küüslaugu seos piirkonnaga oli nõrk ja korraldajatel puudus ettekujutus ürituse kaugematest eesmärkidest. Ühe ürituse sissetöötamine, oma publiku leidmine ja turundamine konkreetse toidutaime kaudu võib olla väga pikaajaline protsess, milles on vajalik erinevate huvipoolte koostöö, mida Jõgeva festivali puhul nappis.

Toidutootjatel, sealhulgas väiketootjatel, on üha olulisem roll tänapäevase regionaalse toidu väljatöötamisel. Piirkonna maitsete taasavastamine ja uute maitsete loomine tugevdab inimeste sidemeid kohaga, kust toit on pärit, kus seda valmistatakse ja süüakse, ning elavdab kahtlemata ka loovust. Erinevalt 
mõnest ajalooliste traditsioonidega kohaspetsiifilisest toidust annab ühe toidutaime uudne kasutamine piirkonna kulinaarse sümbolina vabaduse katsetada ja luua uusi maitseid ja tooteid. Võime tõdeda, et Eesti toidutootjad ongi enamasti üsna uuendusmeelsed ja varmad katsetama erilisi maitsekombinatsioone ja lisandeid. Uutele regionaalsetele toidutoodetele võib aga saatuslikuks saada see, kui toote ümber ei suudeta luua piisavalt kultuurilist tausta (nt erinevaid seostuvaid tegevusi, sündmusi, üritusi vastavas piirkonnas), mis toidu tähendust laiemalt toetaks ja tugevdaks. Tootearendus võib sel juhul muutuda asjaks iseeneses ja katsetamiseks katsetamise pärast. Näiteks küüslaugujäätis või -šokolaad võib nišitootena ehk mõne tarbija maitsmismeeli intrigeerida, nende masstootmine on aga küsitav.

Regionaalse toidu propageerimisel ja arendamisel võib Eestis märgata mitmeid positiivseid külgi: paiga kulinaarse pärandi väärtustamine ja edasikestmine; piirkondliku ja kohaliku toidu tähtsustamine nii tootjate kui ka tarbijate seisukohalt vastukaaluna globaalselt ühtlustavale dieedile; teadlik arutelu, milline on meie toidukultuur ja kuidas me tahame seda teistele esitleda. Ehkki traditsioonide kaubastamine võib aidata piirkonda paremini propageerida, tuleb arvestada ka selle võimalike ohtudega regionaalsele toidukultuurile, selle säilimisele ehedal ja argisel kujul. See on teema, mis nõuab põhjalikumaid uuringuid. Teine edasist uurimist vajav aspekt on traditsioonilise ja uusleiutatud kohaliku toidu esitlemine. Nimelt ei pruugi traditsioone järgiv või neid murdev regionaalne gastronoomia olla välisturistile sama mõistetav või vastuvõetav kui siseturistile, kellele on piirkondlikud maitsed rohkem tuttavad. Oluline on ka küsimus, kas turismile orienteeritud regionaalset toitu tutvustavad üritused ja tooted teenivad pikemas perspektiivis selle piirkonna kultuurilise, sotsiaalse ja majandusliku jätkusuutlikkuse huve.

Uuritud näidete põhjal väidame, et toidutooted ja toiduturism ei pruugi olla regionaalse arengu võti, pigem aitavad nad piirkonna arengule lihtsalt kaasa. Eesti maapiirkondade tulevik, sh sealne (väike)ettevõtlus, on kompleksset riiklikku regionaalpoliitikat eeldav küsimus. Sellegipoolest leiame, et mõtestatult valitud ja tõlgendatud regionaalne toidutaim võib igale piirkonnale pakkuda võimalusi tootevaliku mitmekesistamiseks, piirkonna (kulinaarse) identiteedi tugevdamiseks ning aitab seeläbi suurendada nii kultuurilist kui ka majanduslikku püsimajäämist üleilmastuvas maailmas ja globaalses konkurentsis. 


\section{Kommentaarid}

1 Artikli valmimist on toetanud institutsionaalne uurimistoetus IUT 22-5, IUT 3432; Euroopa Regionaalarengu Fond (Kultuuriteooria Tippkeskus) ja grant ETF9419; Saaremaal toimunud välitöid toetas projekt EKKM14-300 ja RMK. Autorid tänavad kahte anonüümset retsensenti märkuste eest, mis aitasid artiklit paremaks teha.

${ }^{2}$ Need toidutaimed on loomulikult kasutusel ka mujal Eestis ja maailmas, meie valik lähtub just nimetatud regioonide enda loodud kuvandist.

3 Terroir on niiöelda piirkonna maastiku maitse, mis avaldub konkreetses toidus ja on kombinatsioon klimaatilistest ja geoloogilistest kasvutingimustest, vastava kultuuri kasvatamise ja toidu valmistamise oskustest. Toiduteadlane Amy Trubek rõhutab, et ehkki veinikasvatuses ja põllumajanduses on arusaam koha maitsest sajandeid vana, on koha, maitse ja toidu kvaliteedi seostamine võrdlemisi uus nähtus, mis on tekkinud reaktsioonina muutustele toiduturgudel, põllumajanduses ning loomakasvatuses ja ka poliitikas (Trubek 2008: 22).

4 Pikemalt http://www.tastingeurope.com/routes (Tasting Europe. Routes).

5 Pikemalt http://www.clausmeyer.dk/en/the_new_nordic_cuisine_/manifesto_.html (New Nordic Cuisine manifesto).

${ }^{6}$ Pikemalt http://ec.europa.eu/agriculture/quality/schemes/index_en.htm (Geographical indications and traditional specialities). See seadusandlik akt jõustus Euroopas 1992. aastal. Seadusliku regulatsiooni eesmärk on kaitsta regionaalsete toidutoodete reputatsiooni, propageerida põllumajandustegevust, aidata toidutootjatel saada autentsete toodete eest õiglast hinda ning ära hoida ebaõiglast konkuretsi ja tarbijate eksitamist mitte-ehedate toodetega, mis võivad olla kvaliteedilt originaalist kehvemad ja teistsuguse maitsega. Samas on kriitikud leidnud, et märgistamise seadus kaitseb eeskätt tootjaid, sest paljud tarbijad ei suuda autentsel ja mitte-autentsel tootel alati vahet teha.

7 http://www.taste-of-scotland.com.

$8 \mathrm{http} / / / \mathrm{www}$.vastsverige.com/en/.

$9 \mathrm{http} / / /$ www.infactoproject.eu/.

${ }^{10}$ Laiemalt on uurimuse taustaks RK ja RS pikaajaline etnobotaaniline uurimistöö, mis käsitleb Eestis looduslikult kasvavate toidutaimede ajaloolist ja tänapäevast kasutust (Kalle \& Sõukand 2013) ja EB uurimistöö Eesti maaelu muutuste, uute elamusettevõtluse vormide ja kaasaegse restoranikultuuri teemadel (Bardone 2013).

${ }^{11}$ Intervjuude pikkus oli kuni 1,5 tundi, üksikutel kordadel rohkem, ja need toimusid üldjuhul intervjueeritava kodus. Valimi moodustavad üle 40aastased Saaremaalt pärit ja seal püsivalt elanud inimesed; mehed ja naised on võrdselt esindatud ja nende elukohad katavad kogu Saaremaa. Välitööde andmed on autorite valduses ja antakse pärast litereerimist ja süstematiseerimist üle Eesti Kirjandusmuuseumi Eesti Rahvaluule Arhiivi.

${ }^{12}$ Selle aja jooksul toimus mitteformaalseid põgusaid vestlusi ligi 50 inimesega, kes on müünud küüslauku või küüslaugust valmistatud toite.

${ }^{13}$ Sama seis oli ka 1920. aastatel: enne suurenes sibulakasvatus just selle tõttu, et neid viidi suurel hulgal Venemaa linnadesse, vabariigi tekkimisega kadus turg ja sibulakasvatus kuivas peaaegu kokku (PVL 1936a), kuigi välisriikides säilis väga suur huvi Eesti sibula vastu ja hindki oli soodne (PVL 1937). 
${ }^{14}$ Peipsiäärse sibula toidukvaliteedikavas on piiritletud tootjate ala põhjast Raja [dokumendis nimetatakse ekslikult Rae] külast kuni Lüübnitsa [dokumendis kasutatakse vana nimekuju Ljubnitsa] külani lõunas ja Piirissaare saar.

${ }^{15}$ Viimase kümne aasta jooksul on kohalikku teeäärset kaubandust negatiivselt mõjutanud uus Raja küla ümbersõit: varem sõitis maantee läbi küla ja inimesed said otse maja kõrval müüa, uue tee tegemisega suunati aga liiklus ümber. Vähe sellest: küla keskele paigaldati teepervedele peatumist segavad tõkked ja müüjate juurde nii lihtsalt enam ei pääse.

${ }^{16}$ Saaremaa, nagu paljude teistegi Eesti turismisihtkohtade, probleemiks on hooajalisus - ka Lümanda söögimaja on talvel suletud.

17 Tööstuse Saare Õlu erinevate kadakaõlle pudelite siltidega saab tutvuda http://web. zone.ee/olleelu/saareolu.htm.

${ }^{18}$ Samas pole kuusevõrsesiirupi tegemine ka Eesti mandriosas traditsiooniline, vaid uustekkeline, kuid Soomes on see müügil nii gurmeepoodides kui ka supermarketites ja paiguti tehakse seda tänini ka kodudes.

${ }^{19}$ Veebilehel http://www.nationalgarlicday.com/garlic-festivals.html\#.VCZXrxZvAko välja toodud andmetest selgub, et ainuüksi suuremaid festivale on maailmas üle 20 .

\section{Internetiallikad}

Alev, Mati 2014. Küüslaugufestival lahkub Jõgevalt. Vooremaa 4. november (http:// www.vooremaa.ee/contents.php?cid=1028370 - 5. veebruar 2015).

Delfi 21. juuli 2014. Riik toetab Peipsi-äärse piirkonna arengut üle veerand miljoni euroga (http://www.delfi.ee/news/paevauudised/eesti/riik-toetab-peipsi-aarse-piirkonnaarengut-ule-veerand-miljoni-euroga.d?id=69391927 - 5. veebruar 2015).

Heiberg, Signe 2012. Rae valla sibulaosturetk süstis Peipsi-äärsele rahvale lootust (http://eestielu.delfi.ee/eesti/harjumaa/rae/elu/rae-valla-sibulaosturetk-sustis-peipsiaarsele-rahvale-lootust.d?id=65215798 - 5. veebruar 2015).

Kadakas_2014. Harilik kadakas. Vikipeedia. Vaba entsüklopeedia (http://et.wikipedia. org/wiki/Harilik_kadakas - 5. veebruar 2015).

Kallas, Ene 2013. Siirupiemanda magus elu. Postimees. Tarbija (http://tarbija24. postimees.ee/2597466/siirupiemanda-magus-elu - 5. veebruar 2015).

Kalmus, Kertu 2014. Siirupiemandate unistus kadakamarmelaadist täitus. Saarte Hääl. (http://www.saartehaal.ee/2014/06/06/siirupiemandate-unistus-kadakamarmelaadisttaitus/ - 5. veebruar 2015).

Kauplemistingimused_2014. Kauplemistingimused Lüübnitsa sibula- ja kalalaadal. Mikitamäe vald. Kodulehekülg (http://www.mikitamae.ee/index.php/77-kultuur/393kauplemistingimused-luubnitsa-sibula-ja-kalalaadal - 5. veebruar 2015).

Laine, Aare 2014. Leedri küla kadakapäev läks väga korda. Saarte Hääl 15. juuli (http:// www.saartehaal.ee/2014/07/15/leedri-kula-kadakapaev-laks-vaga-korda/ - 5. veebruar 2015). 
Legend_2014. Legend Saaremaa kadakasiirupist. Saaremaa kadakasiirup. Kodulehekülg (http://www.saaremaakadakasiirup.ee/LEGEND-SAAREMAA-KADAKASIIRUPIST 5. veebruar 2015).

Leib_2014. Kadakaleib. Saaremaa Käsitöö Toidu Tegijad. Saaremaa Turundusühingu lehekülg(http://www.saaremahe.ee/tootearendus/files/Download/Retseptid\%20leader\%20 kadakaleib.pdf - 5. veebruar 2015).

Leib2_2014. "Kena ja kröbe” Kadakamarjaleib. Gourmet Club (http://www.vertigogourmet. ee/et/tooted/Leivad/kadakamarjaleib/ - 5. veebruar 2015).

Lember, Ain 2011. Saaremaa kadakasiirup on enimmüüdud uudistoode. Saarte Hääl 2. november (http://www.saartehaal.ee/2011/11/02/saaremaa-kadakasiirup-on-enimmuudud-uudistoode/ - 5. veebruar 2015).

Lukas, Jaan 2012. Marika Tuus-Laul tõi "Peipsi sibula" temaatika Riigikogu infotundi. Delfi. Eesti Elu (http://eestielu.delfi.ee/eesti/tartumaa/tartu/elu/marika-tuus-laul-toipeipsi-sibula-temaatika-riigikogu-infotundi.d?id=65322958 - 5. veebruar 2015).

Maaleht 6. juuni 2014. Saaremaine kadakamarmelaad valmib hoopis mandril. Maaleht.ee (http://maaleht.delfi.ee/news/tarbija/tarbijauudised/saaremaine-kadakamarmelaadvalmib-hoopis-mandril.d?id=68825667 -5 . veebruar 2015).

Maaleht 11. juuli 2013. Peipsi-äärse piirkonna arengu toetamiseks eraldati 348000 eurot. Maaleht.ee (http://maaleht.delfi.ee/news/uudised/eestiuudised/peipsi-aarse-piirkonnaarengu-toetamiseks-eraldati-348-000-eurot.d?id=66426908 - 5. veebruar 2015).

Menüü_2014. Kolkja kala-sibularestorani menüü. Kolkja kala-sibularestoran (http:// www.hot.ee/k/kolkjarestoran/menyy_est.html - 5. veebruar 2015).

Menüü2_2014. Lümanda söögimaja menüü. Lümanda söögimaja (http://www.soogimaja. planet.ee/index.php?l=2 - 5. veebruar 2015).

Mikovitš, Bianca 2012. Viimsi rahvas tahab Rae valda sibulaostus ületada. Maaleht.ee (http://maaleht.delfi.ee/news/uudised/eestiuudised/viimsi-rahvas-tahab-rae-valdasibulaostus-uletada.d?id=65196320 -5 . veebruar 2015 ).

Niitra, Sirje 2013. Maitsvat Peipsi sibulat tänavu kõigile ei jagu. Postimees. Tarbija (http://tarbija24.postimees.ee/1823668/maitsvat-peipsi-sibulat-tanavu-koigile-ei-jagu 5. veebruar 2015).

Saaremaa_2014. Saaremaa sümbolid (http://visitsaaremaa.ee/index.php?lang=et\&page_ $\mathrm{id}=22-5$. veebruar 2015 ).

Saaremaajuust_2014.Saarejuust.ee (http//www.saarejuust.ee/index.php?page=8\&tootegrupp=11\&id=505. veebruar 2015).

Sinep_2014. Mustjala Mustard (http://www.mustjala-mustard.de/index.php?page=shop. product_details\&flypage=flypage.tp-ecommerce.tpl\&product_id=31\&category_ $\mathrm{id}=6 \&$ option=com_virtuemart\&Itemid=40\&lang=et -5 . veebruar 2015).

Tamm, Ülle 2013. Põhja-Eesti kohaliku toidu märgis - Arenduskoda laiendab projekti üle Harju- ja Virumaa. Sõnumitooja 14. mai (http://sonumitooja.ee/pohja-eesti-kohalikutoidu-maergis-arenduskoda-laiendab-projekti-uele-harju-ja-virumaa/ - 5. veebruar 2015). 
Toidukvaliteedikava "Peipsi sibul" eeskiri (http://www.vet.agri.ee/static/files/1293. Toidukvaliteedikava_eeskiri.pdf - 6. veebruar 2015).

Meyer, Claus. The New Nordic Cuisine Movement. Manifesto. Meyers (http://www. clausmeyer.dk/en/the_new_nordic_cuisine_/manifesto_.html - 6. veebruar 2015).

Quality policy. Geographical indications and traditional specialities. Agriculture and Rural Development. European Commission (http://ec.europa.eu/agriculture/quality/ schemes/index_en.htm - 6. veebruar 2015).

National Garlic Day. The Party Excuses.com Network (http://www.nationalgarlicday. com/garlic-festivals.html\#.VCZXrxZvAko - 6. veebruar 2015).

Sibulatee - üks piirkond, kaks rahvust, kolm kultuuri. Sibulatee (http://www.sibulatee. ee/ - 6. veebruar 2015).

Saare Õlu (http://web.zone.ee/olleelu/saareolu.htm - 6. veebruar 2015).

Taste of Scotland (http://www.taste-of-scotland.com - 6. veebruar 2015).

European gastronomic routes. Routes. www.visiteurope.com (http://www.tastingeurope. com/routes - 6. veebruar 2015).

Eesti toit. Eesti Toidutee (http://www.toidutee.ee/ - 6. veebruar 2015).

West Sveden (http://www.vastsverige.com/en/ - 6. veebruar 2015).

\section{Kirjandus}

Adema, Pauline 2009. Garlic capital of the world: Gilroy, Garlic, and the making of a festive foodscape. Oxford: University Press of Mississippi.

Bardone, Ester 2013. My Farm is My Stage: A Performance Perspective on Rural Tourism and Hospitality Services in Estonia. Doctoral dissertation. Tartu: Tartu University Press (http://dspace.utlib.ee/dspace/bitstream/handle/10062/34504/bardone_ester.pdf?sequence=1 5. veebruar 2015).

Bell, David \& Valentine, Gill 1997. Consuming geographies: we are where we eat. London \& New York: Routledge.

Böttner, Johannes 1913. Aiatöö õperaamat. J. Böttneri aiatöö-raamatute järele Läänemere maadel ja Venemaa kaugemates kubermangudes asuvate eestlaste jaoks kokku seatud. Tallinn: Teadus.

Dare, Rebecca \& Jönsson, Håkan \& Knutsson, Hans 2013. Adding Value in Food Production. Muzzalupo, Innocenzo (toim). Food Industry InTech, lk 669-697 (doi: 10.5772/53174).

Donald, Betsy \& Gertler, Meric \& Gray, Mia \& Lobao, Linda 2010. Re-regionalizing the food system? Cambridge Journal of Regions, Economy and Society 3, lk 171-175 (doi: 10.1093/cjres/rsq020).

Everett, Sally \& Aitchison, Cara 2008. The Role of Food Tourism in Sustaining Regional Identity: A Case Study of Cornwall, South West England. Journal of Sustainable Tourism 16 (2), lk 150-167 (doi: 10.2167/jost696.0). 
Guerrin, Triinu \& Karu, Kadri 2014. Võrokõisi köögi- ja söögiraamat. Võru: Võro Instituut.

Hall, Colin Michael \& Cambourne, Brock \& Sharples, Liz \& Macionis, Nicki \& Mitchell, Richard (toimd) 2003. Food Tourism Around the World: Development, Management and Markets. Elsevier, Oxford: Butterworth-Heinemann.

Hjalager, Anne-Mette \& Richards, Greg (toimd) 2002. Tourism and gastronomy. London: Routledge.

Hobsbawm, Eric \& Ranger, Terence 1983. The Invention of Tradition. Cambridge: Cambridge University Press.

Kalle, Raivo \& Sõukand, Renata 2013. Eesti looduslikud toidutaimed: kasutamine 18. sajandist tänapäevani. Tallinn: Varrak.

Kneafsey, Moya 2010. The region in food - important or irrelevant? Cambridge Journal of Regions, Economy and Society 3, lk 177-190 (doi: 10.1093/cjres/rsq012).

Kuvaitseva, Marina 2010. Zastolitsa. Kukhnia staroverov Estonii. Tartu: Huma.

Koor, Jaan 1889. Koka-raamat 482 söögivalmistamise õpetusega. Tartu: K. A. Hermann.

Kõiv, Krista \& Lambur, Reve 2012. Statistika - põllumajanduse ja kohaliku toiduga seotud Leader-meetme projektid. Kõiv, Helen \& Lambur, Reve (toim). Leader - kohaliku toidu arenguks! Eesti maaelu arengukava 2007-2013. Leader-meetme projektid. Jäneda: Maamajanduse Infokeskus, lk 50-51 (http://www.digar.ee/arhiiv/et/raamatud/89909 5 . veebruar 2015).

Leeds-Hurwitz, Wendy 1993. Semiotics and Communication: Signs, Codes, Cultures. Hillsdale; New Jersey: Lawrence Erlbaum Associates Publishers.

Ladõnskaja, Viktoria 2011. Peipsi veerel: vanausulised paluvad lauda. Tallinn: Ajakirjade Kirjastus.

Mesikäpp, Laivi \& Kivisalu, Indrek 2012. Seto köök: põlvest põlve. Tallinn: Setomaa Tulevik.

Moora, Aliise 1964. Peipsimaa etnilisest ajaloost: ajaloolis-etnograafiline uurimus EestiVene suhetest. Tallinn: Eesti Riiklik Kirjastus.

Moora, Aliise 1982. Mida vanasti kasemahlast tehti. Eesti Loodus 5, lk 298-300.

Moora, Aliise 1984. Kuidas vanasti kadakamarju kasutati. Eesti Loodus 6, lk 378-380.

Mänd, Anu 2004. Pidustused keskaegse Liivimaa linnades 1350-1550. Tallinn: Eesti Keele Sihtasutus.

Mätas, Mare 2009. Kihnu kokaraamat. Kihnu: Kihnu Kultuuriruum.

Pagland, Hilda 1933. Liha alalhoid, kasutamine ja vorstide valmistamine. 2. tr. Tallinn: Eesti Maanaiste Keskselts.

Pihlik, Ulve 2006. 100 maitsetaime. Tallinn: Ajakirjade Kirjastus.

Pine, B. Joseph \& Gilmore, James H. 1999. The Experience Economy: Work is Theatre and Every Business a Stage. Boston; Massachusetts: Harvard Business School Press.

PVL 1923 = -gor. Kas ei võiks hakata suuremal arvul sibulaid kasvatama? Päevaleht 141, 2. juuni, lk 10. 
PVL 1934 = Järvamaalt. Sibulakaupmeeste killavoorid. Päevaleht 246, 7. september, lk 6 . PVL 1936a = Wer. Peipsiäärsetest sibulakasvatajate küladest. Külad, kus pooled põllud on sibulapeenardeks. Tänavune saak kujuneb hulga vähemaks. Päevaleht 191, 18. juuli, lk 8 .

PVL 1936b = Peipsi sibulate harukordne hinnatõus. Peipsiäärne sibulakasvatus on vähenenud. Päevaleht 307, 12. november, lk 5.

PVL 1937 = Sibulakasvatus laiendamisele. Päevaleht 293, 28. oktoober, lk 6.

Richards, Greg 2012. An overview of food and tourism trends and policies. Food and the Tourism Experience. The OECD-Korea Workshop. OECD Publishing (doi: 10.1787/9789264171923-en).

Suitsu, Maire 2009. Säästlikult ja suupäraselt. Tallinn: Varrak.

Sõukand, Renata \& Kalle, Raivo 2011. Change in medical plant use in Estonian ethnomedicine: A historical comparison between 1888 and 1994. Journal of Ethnopharmacology 135 (2), lk 251-260 (doi: 10.1016/j.jep.2011.02.030).

Taavet, Ave 2013. "Kala vanausuliste moodi": Toit identiteedimarkerina Eesti Peipsiäärsetel vanausulistel. Hunt, Jaanika (toim). Rabatuluke: Pro Folkloristica XVII. Tartu: Eesti Kirjandusmuuseum, lk 19-31.

Trubek, Amy B. 2008. The taste of place: A cultural journey into terroir. Berkeley; Los Angeles; London: University of California Press.

Viires, Ants 2000. Puud ja inimesed. 2. tr. Ilmamaa: Tartu.

\title{
Summary
}

\section{Onion, Juniper and Garlic: Food Plants and Regional Food Culture in Estonia}

\author{
Raivo Kalle, Ester Bardone, Renata Sõukand
}

Keywords: garlic, Jõgeva Garlic Festival, onion from Lake Peipsi area, regional food culture, Saaremaa juniper

The article discusses the role of food producers and tourism industry in shaping Estonian regional food traditions. The authors base their study on three regional culinary symbols - onion from the area of Lake Peipsi, juniper from Saaremaa Island and garlic in the focus of Jõgeva Garlic Festival - and analyse the way that a region can define itself, both culturally and economically, by means of a concrete plant.

Different regions compete as tourist destinations and food plays an important role in the shaping and marketing of such destinations. Throughout times seeking for authentic experience has been an issue of some significance in tourism. For a tourist, genuine food experience inherent in a particular region could add extra value: food can be consumed on the spot; while eating or buying food one can socialise with local people; food products can be taken back home as culinary souvenirs; photographs taken of the meals eaten during travels can be shared with friends on Facebook, etc. There is a whole range of 
niche products and services in food tourism: food festivals, wine tasting trips, cooking courses conducted by local chefs, etc.

In recent decades, Estonia, like other European countries, has been searching for and rediscovering the regional features of food culture. Both on state and local levels attempts have been made to define Estonian food, to find customers for local food on globalised markets, etc. The Estonian Culinary Route website (http://www.toidutee.ee/), which introduces local food to domestic and foreign tourists, emphasises that Estonia is comprised of six unique food regions - northern Estonia, eastern Estonia, southern Estonia and Mulgimaa, Setomaa, western Estonia with the islands (Hiiumaa, Saaremaa and Muhumaa), and two smaller ones (Kihnu Island and Old Believers' villages in Lake Peipsi area) - and adds that each region has preserved its historically evolved unique dishes and food culture. So the generalised national cuisine model has moved towards mapping more diverse and regionally varying Estonian food culture. Emphases on the peculiarities of food regions help the entrepreneurs in food manufacturing and catering differentiate from one another. Just like in Scandinavia, top chefs foster food culture in Estonia; for instance, the project "Landscape on a plate 2014-2020", initiated by Dimitri Demyanov merges the cuisines of different Estonian regions: southern Estonia (Võru County), Setomaa, Mulgimaa and Old Believers' cuisines and those of the coastal regions and islands.

The three food plants on which the article focuses aptly illustrate the usage possibilities and problems associated with a plant as a symbolic culinary identity marker.

In the case of the onion from Lake Peipsi area, one can speak about the valuing of the region's plant cultivation and food traditions, but also about marketing the plant. Historical tradition is an extra value in its own right, and is easier to sell as authentic. The difference as compared to the other two examples is that in Lake Peipsi area it is the primary product itself rather than food products and dishes made of onion that is marketed.

The juniper from Saaremaa Island offers an interesting example of the intertwined traditions and innovation, as well as the natural and cultural, on the example of one food plant. Juniper has grown in Saaremaa for centuries, and it still does, and has been used as a food plant earlier on, which helps to create cohesion between the region and traditions. Today juniper is used to add regional flavour to food, and in addition to older, culinary use, novel product development solutions are searched for, a good example of which is juniper syrup.

In comparison with the former two, Jõgeva Garlic Festival is probably the most recent example of a consciously created regional (culinary) identity, which combines several cultural elements of different origins. Estonia has no historic tradition of garlic growing or usage. So it is definitely an 'invented tradition', which relates to similar events with a comparatively short history in other parts of the world, which try to advocate a region by means of a food and a food festival.

On the basis of the explored examples the authors maintain that food products and food tourism need not be a key to regional development; they rather simply contribute to the development of a certain region. The future of Estonian rural regions, including (small-scale) enterprises, requires complex regional politics on state level. Nevertheless, a consciously chosen and interpreted local food plant could offer opportunities to a region to diversify the product range, strengthen the (culinary) identity of the region, and thereby enhance both cultural and economic survival in the globalising world and global competition. 